Јелена М. Ковач ${ }^{1}$

Међународна школа

Београд удк 811.163.41'373.612.2

811.134.2'373.612.2

811.163.41'373.612.2:811.134.2'373.612.2

DOI https://doi.org/10.18485/zivjez.2017.37.1.5

Прегледни научни рад

\title{
КОНЦЕПТУАЛИЗАЦИЈА ПОЗИТИВНОГ И НЕГАТИВНОГ КРОЗ МЕТАФОРЕ СА БЕЛОМ И ЦРНОМ БОЈОМ КАО ИЗВОРНИМ ДОМЕНИМА У СРПСКОМ И ШПАНСКОМ ЈЕЗИКУ
}

Циљ овог рада је да издвојимо одређен број израза са белом и црном бојом у српском, односно шпанском језику као илустрацију да се у оба језика користе исте метафоре за означавање позитивног, односно негативног. Корпус је ексцерпиран из једнојезичних речника̂ српског и шпанског језика, као и из речника̂ српске и шпанске фразеологије. Резултати истраживања показали су да у српском језику изрази са белом бојом у већини случајева имају позитивну конотацију, док се у шпанском ови изрази односе углавном на негативне концепте. Када је реч о изразима са црном бојом, они се у оба језика искључиво користе за концептуализацију негативног.

Кључне речи: метафоре, појмовне метафоре, бела боја, црна боја, концептуализација позитивног и негативног, српски и шпански.

\section{1. Увод}

Полазећи од чињенице да боје, као и концептуализовање одређених појмова путем метафоричких израза који садрже називе за боје, заузимају важан део у људском постојању, у овом раду бавићемо се метафорама са белом и црном бојом у српском и шпанском језику из перспективе когнитивне лингвистике. За потребе истраживања, узећемо у обзир концептуализацију позитивног и негативног у српском и шпанском, што је изражено путем метафора са белом и црном бојом. С обзиром на то да боје стварају одређене асоцијације у нашој свести, полазимо од хипотезе да се у оба језика користе метафоре са

1 kovac.jelena@gmail.com 
белом и црном бојом као изворним доменима како би се означило добро/позитивно, односно лоше/негативно.

Теоријски део рада представља кратак осврт на концепт метафора̂ уопште, као и појмовних метафора, а затим се усмеравамо на боје и њихово метафоричко значење. У наставку рада бавимо се анализом израза који садрже називе за белу и црну боју које смо издвојили из српских и шпанских речникаิ. Како бисмо прикупили метафоричке изразе са белом и црном бојом у српском језику, користили смо један једнојезични и један фразеолошки речник. Када је реч о изразима на шпанском, користили смо два једнојезична речника̂ шпанског језика и један шпански фразеолошки речник (податке в. у поглављу 4).

Циљ овог истраживања је да путем метафора са белом и црном бојом покажемо да се позитивно и негативно у оба језика концептуализује на исти начин (бела боја/позитивно, црна боја) негативно). Напомињемо да циљ рада није свеобухватна анализа свих израза са белом и црном бојом у српском и шпанском језику. Очекујемо да ће истраживање потврдити почетну хипотезу где се бело користи за позитивно концептуализовање, а црно за негативно, међутим, не искључујемо могућност наилажења на одређена одступања.

\section{2. Метафоре}

Метафоре се традиционално везују за песништво, сликовито изражавање на које наилазимо у оквиру књижевноуметничког текста, што указује на то да се метафора поима као стилска фигура, као украс текста који писци примењују како би се код слушалаца изазвао нарочити ефекат (Кликовац 2004: 10).

Иако за већину људи метафора представља средство песничке имагинације, као и реторичко средство, које је искључиво ограничено на језик, метафора свакако излази из језичких оквира и присутна је у свакодневном животу људи, у људским мислима и делима (Лејкоф, Џонсон 2003 [1980]: 4). Људски појмовни систем, у великој мери, метафоричан је по својој природи, тако да је начин на који мислимо, уобличавамо концепте, поимамо, повезан са метафорама (Лејкоф, Џонсон 2003 [1980]: 
4), што нас даље усмерава на план когнитивне лингвистике и појмовних метафора.

\section{1. Појмовне метафоре}

Когнитивна лингвистика поставила је метафору у оквире мисаоног процеса, као један од значајних принципа човековог појмовног система (Махон 1999, према Кликовац 2004: 10-11), тако да је овде реч о појмовној метафори. Појмовне метафоре се, међутим, веома често користе несвесно (Гоутли 2007: 35).

Метафора прожима свакодневни живот људи с обзиром на то да је присутна у људским мислима и делима, да чини саставни део мишљења, а не само део свакодневног или песничког језика. Процеси људских мисли су у значајној мери метафорични (Лејкоф, Џонсон 2003 [1980]: 4-6).

Појмови, као и њихово уобличавање, метафорички су структурирани на систематски начин, приликом чега се користе појмови из једном домена да се говори о одговарајућим појмовима у метафорички дефинисаним доменима (Лејкоф, Џонсон 2003 [1980]: 53). Када је реч о метафорама и доменима, постоје два домена: изворни домен и циљни (Лејкоф, Џонсон 2003 [1980]: 266-267).

„Механизам метафоре састоји се у пресликавању структуре једног појма (или појмовног домена), који је обично чулно сазнатљив и добро познат, на други домен“ (Кликовац 2004: 11-12) који је апстрактан.

Међу изворне домене, тј. домене који позајмљују своју структуру (Кликовац 2004: 12), спадају боје. У наставку рада бавићемо се белом и црном бојом у српском и шпанском језику као изворним доменима како би се означило добро/позитивно, односно лоше/негативно.

\section{3. Боје и (ван)језичка стварност}

Боје играју веома значајну улогу у језику с обзиром на чињеницу да функционишу као незаобилазни елемент људске перцепције ванјезичке стварности (Хрњак 2000: 203, према 
Опашић, Спицијарић 2010: 122). Боје „су саставни чинилац визуелног доживљаја света који нас окружује“ (Лазаревић 2013: 1), стога су присутне у многим аспектима живота и предмет су истраживања различитих научних дисциплина (Рубио Хименес 2015: 3), те самим тим и лингвистичких наука.

Након спроведеног истраживања, Брент Берлин и Пол Кеј (1969: 2), навели су да постоји једанаест категорија основних боја: бела, црна, црвена, зелена, плава, жута, наранџаста, розе, љубичаста, сива и браон, стога се у метафоричким изразима обично сусрећемо са наведеним бојама као изворним доменима. Поменуто истраживање показало је да у сваком од испитиваних језика постоје изрази за белу и црну боју (Брент, Кеј 1969: 2).

Како наводи Милка Ивић (2002: 36) у науци је утврђено да је за метафоризовање колористичких назива од пресудног значаја то како људи гледају на ентитет којем је дата боја карактеристично својство. Саме боје аутоматски стварају одређене асоцијације у нашој свести и покрећу позитивне или негативне конотације.

\section{1. Метафоричка проширења назива за бело и црно}

Када је реч о белој и црној боји, метафоричке екстензије назива за бело обично се усмеравају у правцу идентификовања позитивног, док, са друге стране, црно, у највећем броју случајева, покреће негативну конотацију (Ивић 1995: 21).

Како наводи Ивић (1995: 15) „бело и црно се перцептивно и психолошки доживљавају као два међусобно супротстављена екстрема у низу постојећих колористичких датости, а индивидуалитети ових су устројени и по критеријуму растуће/ опадајуће светлине, односно тамноће, тако да се на апсолутном крају нарастајућег светлог налази бело, а на апсолутном крају нарастајућег тамног ирно." У језицима бело је једним делом одређено својом антонимијском повезаношћу са називом за црно, одакле проистиче да се бело односи на светло/исправно/позитивно, док је црно синоним за тамно/неисправно/негативно (Ивић 1995: 16).

Негативно психолошко доживљавање ирног човекова је исконска особина будући да су људи одувек зазирали од таме и непознатог, нечег тајанственог што су наслућивалу у тами (Иванов 
КОНЦЕПТУАЛИЗАЦИЈА ПОЗИТИВНОГ И НЕГАТИВНОГ...

и Топаров 1965: 201, према Ивић 1995: 17). С обзиром на поменуту чињеницу, конотације негативног, опасног и злослутног уткане су у значењски потенцијал ознаке за црну боју у бројним језицима света (Кикући, Лихтенберк 1983: 31, према Ивић 1995: 18).

У наставку рада, путем метафоричких израза које смо издвојили из српских и шпанских једнојезичних и фразеолошких речника̂, показаћемо начин на који се концептуализује позитивно и негативно у српском и шпанском језику, изражен кроз метафоричке изразе са белом и црном бојом.

\section{4. Концептуализација позитивног и негативног путем метафора са белом и црном бојом као изворним доменима}

У овом одељку бавићемо се анализом израза који садрже називе за белу и црну боју које смо издвојили из српских и шпанских речника̂. За потребе истраживања израза на српском језику, користили смо Речник српскохрватскога књижевног језика (Матица српска, Матица хрватска 1967; 1976), као и Фразеолошки речник српског језика (Оташевић 2012). Што се тиче израза на шпанском језику, издвојили смо корпус из два једнојезична речника̂ шпанског језика и једног шпанског фразеолошког речника: Diccionario de uso del español actual (КЛАВЕ 2000), Diccionario de la lengua española (Шпанска краљевска академија 2014), Diccionario de fraseología española: locuciones, idiotismos, modismos y frases hechas usuales en español [su interpretación] (Кантера Ортис де Урбина, Гомис Бланко 2007).

\section{1. Изрази са белом бојом (el color blanco)}

Као што смо навели у претходном одељку, метафоричка проширења назива за бело, углавном су усмерена у правцу идентификовања позитивних концепата (Ивић 1995: 21).

Кључне концептуалне метафоре које се могу издвојити из израза прикупљених на српском језику јесу следеће: ДоБРО ЈЕ БЕЛО (Но мисао моја није тако бела; Борба између бијелих и 
црних богова; И бијело и црно у нама живи), СВЕТЛО/СЈАЈНО JЕ БЕЛО (Бијеле оштре муње прокрижају шумом; Бела му светлост на зиду мирује; бели дан), СРЕЋНО ЈЕ БЕЛО (Ноћ вам дође са Вука једнога, данак бели, браћо, са другога; Коิ стабло ширим гране у бескрајне просторе, у бијелу радост невиђеног јутра), СПОКОЈНО/СИГУРНО ЈЕ БЕЛО (Неће никад стићи у бијелу луку мира) и ЧАСНО/НЕВИНО ЈЕ БЕЛО (Да ми је љубав осетити благу о којој не зна, а говори свет, наивну, белу, уживоту злом).

Прикупљени изрази на српском језику иду у прилог хипотези да је концептуализација позитивног изражена белом бојом, међутим, приликом истраживања наишли смо и на изразе који представљају одступање од ове хипотезе, призивајући негативне конотације. Реч је о следећим изразима: бити (живети) на белом хлебу (живети у очекивању најтежег, чеакти извршење смртне казне након изрицања пресуде), ни беле не види (ништа не види, потпуно је пијан), бели свет (туђи крајеви, далеко од куће), бела врана (неко ко се издваја од других, неко врло необичан).

Када је реч о изразима на шпанском језику, коришћени корпус указује на то да се из одређених израза са белом бојом може издвојити концептуална метафора НЕДОСТАТАК ЈЕ БЕО/ ESCACEZ ES BLANCA (estar/quedarse en blanco: занемети, ништа не схватати; pasar la noche en blanco: провести бесану ноћ, не склопити ока), што је оповргло почетну хипотезу истраживаља да је бело усмерено ка позитивним концептима, те да се ова боја не користи за концептуализацију негативног. У шпанском корпусу који смо користили само три израза указала су на концептуалну метафору ПОЗИТИВНО JЕ БЕЛО/ POSITIVO ES BLANCO: dar en el blanco: погодити у мету; bandera blanca: знак предаје, знак пријатељских намера; la magia blanca: бела, добра магија.

\section{2. Изрази са црном бојом (el color negro)}

Приликом спровођења истраживања, било да је реч о српском или шпанском језику, нисмо наишли ни на један метафорички израз који би указао на то да се помоћу црне боје 
КОНЦЕПТУАЛИЗАЦИЈА ПОЗИТИВНОГ И НЕГАТИВНОГ...

концептуализује позитивно, будући да негативно психолошко доживљавање црног представља исконску људску особину (Иванов и Топаров 1965: 201, према Ивић 1995: 17).

У оба језика, на основу прикупљених израза, могу се издвојити следеће концептуалне метафоре: ЛОШЕ ЈЕ ЦРНО/ MALO ES NEGRO (гледати кроз црне наочари (гледати само лоше стране живота, бити песимиста), día negro (лош, неповољан дан), tener la пеgra (имати лошу срећу), црна магија/ la magia negra)), ПРЉАВО/НЕЧИСТО JЕ ЦРНО/SUCIO ES NEGRO (црне руке/manos negras (прљаве руке; овде уочавамо потпуну подударност између српског и шпанског језика)), ТЕШКО JE ЦPHO/DIFÍCIL ES NEGRO (црн живот (тежак живот), vérselas negras (наићи на многе потешкоће), verse alguien negro para hacer algo (имати много потешкоћа приликом реализације неког подухвата)), такође, ИЛЕГАЛНО/НЕЗАКОНИТО ЈЕ ЦРНО/ ILEGAL ES NEGRO (црна берза/mercado negro, dinero negro (новац добијен илегалним путем), en negro (на црно, обично радити на црно)). Као антитеза концептуалној метафори СРЕЋНО ЈЕ БЕЛО, издваја се концептуална метафора НЕСРЕЋНО/ЗЛОСЛУТНО/ЗЛО ЈЕ ЦРНО и СМРТ ЈЕ ЦРНА: црни барјак, црна птица, црни облаци, црна звона, црне године.

Уз помоћ црне боје изражава се и све оно што нема значаја: БЕЗНАЧАJНО JE ЦРНО/INSIGNIFICANTE ES NEGRO (sacar lo que el negro del sermón (немати користи од нечијих савета или од онога што се чује/прочита), црно испод нокта/lo negro de una uña)). За разлику од српског језика, у шпанском језику ЉУТњА JE ЦРНА/RABIA ES NEGRA што илуструју изрази: ponerse alguien negro (изнервирати се), estar negro (бити љут), у српском језику, пак, СРAMOTA JE ЦPHA/VERGÜENZA ES NEGRA: црн образ.

\section{5. Закључак}

Истражујући концептуализацију позитивног и негативног изражену кроз метафоре са белом и црном бојом као изворним доменима у српском и шпанском језику, издвојили смо 
различите појмовне метафоре: ДОБРО ЈЕ БЕЛО, ПОЗИТИВНО ЈЕ БЕЛО/ POSITIVO ЕS BLANCO, СВЕТЛО/СЈАЈНО ЈЕ БЕЛО, НЕДОСТАТАК JЕ БЕО/ЕSCACEZ ЕS ВLANCA, ЛОШЕ JЕ ЦРНО/ MALO ES NEGRO, ПРЉАВO/НЕЧИСТО JЕ ЦРНО/SUCIO ES NEGRO, ТЕШКО JЕ ЦРНО/DIFÍCIL ES NEGRO, БЕЗНАЧАJHO JЕ ЦРНО/ INSIGNIFICANTE ES NEGRO, итд.

Већина издвојених метафора показала је да у српском језику изрази са белом бојом у већини случајева имају позитивну конотацију, док се у шпанском језику ови изрази односе углавном на негативне концепте. Када је реч о изразима који садрже назив за црну боју, у оба језика ови изрази се користе искључиво за концептуализацију негативног.

\section{ЛИТЕРАТУРА}

Брент, Kej 1969: Brent, B. and P. Kay. Basic Color Terms: Their Universality and Evolution. Oxford, Los Angeles, Berkeley: University of California Press.

Гоутли 2007: Goatly, A. Metaphors of Power. In: Washing the Brain: Metaphor and Hidden Ideology. Amsterdam: John Benjamins, pp. 35-87.

Ивић 1995: Ivić, M. O zelenom konju. Novi lingvistički ogledi. Beograd: Biblioteka XX vek.

Ивић 2002: Ivić, M. Red reči. Lingvistički ogledi, četiri. Beograd: Biblioteka $\mathrm{XX}$ vek.

Кликовац 2004: Klikovac, D. Metafore u mišljenju i jeziku. Beograd: Biblioteka XX vek.

Лејкоф, Џонсон 2003 [1980]: Lakoff, G. and M. Johnson. Metaphors We live by. London: The University of Chicago press.

Лазаревић 2013: Lazarević, R. D. Leksičko-semantičko polje boja u italijanskom i srpskom jeziku. Doktorska disertacija. Beograd: Filološki fakultet, Univerzitet u Beogradu.

Опашић, Спицијарић 2010: Opašić, M., Spicijarić, N. Prilog kontrastivnoj analizi frazema sa sastavnicom boje u hrvatskoj, talijanskoj i njemačkoj frazeologiji. Fluminensia, 22 (1), 121-136.

Рубио Хименес 2015: Rubio Jiménez, C. "El lenguaje visual de los colores: historia, cultura y problemas en la traducción de las expresiones idiomáticas de colores". Trabajo fin de grado. Soria: Facultad de traducción e interpretación, Universidad de Valladolid, [online] [http:// 
КОНЦЕПТУАЛИЗАЦИЈА ПОЗИТИВНОГ И НЕГАТИВНОГ...

www.uvadoc.uva.es/bitstream/10324/13753/1/TFG-0\%20586. pdf, приступљено 21. 10. 2015].

РЕЧНИЦИ

Кантера Ортис де Урбина, Гомис Бланко 2007: Cantera Ortiz de Urbina, J., Gomis

Blanco, P. Diccionario de fraseología española: locuciones, idiotismos, modismos y frases hechas usuales en español [su interpretación]. Madrid: Abada Editores.

КЛАВЕ 2000: CLAVE. (2000). Diccionario de uso del español actual. Madrid: Ediciones SM.

Матица српска, Матица хрватска 1967: Матица српска, Матица хрватска. Речник српскохрватскога књижевног језика. Књига прва А-Е. Нови Сад, Загреб: Матица српска, Матица хрватска.

Матица српска 1976: Матица српска. Речник српскохрватскога књижевног језика. Књига шеста С-Ш. Нови Сад: Матица српска.

Оташевић 2012: Оташевић, Ђ. Фразеолошки речник српског језика. Нови Сад: Прометеј.

Шпанска краљевска академија 2014: Real Academia Española. Diccionario de la lengua española (23.a ed.), [Online] [http://www. dle.rae.es/?w=diccionario, приступљено 27. 10. 2015].

\section{Jelena M. Kovač}

\section{CONCEPTUALIZATION OF A POSITIVE AND NEGATIVE THROUGH METAPHORS WITH WHITE AND BLACK COLOUR AS A SOURCE DOMAIN IN SERBIAN AND SPANISH LANGUAGE}

Summary

Regarding the fact that colours represent an important part of human existance, this paper deals with metaphorical colour expressions containing white and black both in Serbian and Spanish. These expressions represent the way we conceptualize positive or negative concepts, therefore, we tend to collect a certain number of those metaphors both in Serbian and Spanish. Given the fact that colours create certain connections 
in our mind, we part from the hypothesis that in both languages metaphors with white and black colour as a source domain have been used to indicate good/positive and bad/negative. The aim of the paper is to abstract certain number of metaphorical expressions containing white and black in Serbian and Spanish, which should illustrate that in both languages exist the same metaphors to mark the positive and the negative concepts. The corpus we use for our research has been excerpted from monolingual Serbian and Spanish dictionaries, as well as from Serbian and Spanish phraseological dictionaries. The results of the research have shown that Serbian expressions with white colour in a majority of cases have a positive connotation, whereas in Spanish these expressions refer mainly to the negative concepts. When it comes to the expressions containing the black, in both languages these expressions are used to conceptualize solely the negative.

Key words: metaphors, conceptual metaphors, white, black, conceptualization of positive and negative, Serbian and Spanish. 